\title{
Roadblocks to laws for healthy eating and activity
}

\author{
Nola M. Ries MPA LLM, Barbara von Tigerstrom LLB PhD
}

Previously published at www.cmaj.ca

$\mathrm{M}$ odern environments promote overeating and sedentary behaviour, and the resulting epidemic of chronic disease is a major public health challenge of the early 21 st century. Governments and experts around the world are sounding the alarm about the medical, economic and social costs of escalating rates of obesity, diabetes, cardiovascular disease and cancer, and are demanding concerted action, including legislative measures, to promote healthier nutrition and physical activity. A recent report from the World Cancer Research Fund and the American Institute for Cancer Research asserts: "The increase in consumption of sugary drinks and of convenient processed and 'fast food,' the decline in physical activity, and the consequent rapid rise in overweight and obesity ... now amounts to a global public health emergency that requires government intervention. ... Specifically, government intervention needs to take the form of appropriate legal and fiscal measures designed to make healthy choices more affordable, accessible, and acceptable."'

Health reports from Canada and other countries are uniform in their calls for coordinated and comprehensive measures — including legal measures — to promote healthier diets and physical activity (Table1). ${ }^{2-11}$ Many jurisdictions in the United States regulate food and physical activity standards in schools, and 20 states require measurements of body mass index or other weight-related screening of schoolchildren. ${ }^{12}$ Thirty states have implemented taxes on soft drinks and foods of low nutritional value, and a growing number of states and local governments require that chain restaurants post nutritional information on menus. The province of Quebec and Sweden and Norway have restricted advertising to children for many years, and the telecommunications regulator in the United Kingdom now restricts food advertising aimed at children.

Despite the recommendations in Canadian government reports and legal precedents elsewhere, governments in Canada have taken little legislative action to promote healthy eating and physical activity (Table 2). Legal measures are sparse, with little consistency across the country. Three factors might explain this reticence: concern about legislative authority, ideological opposition to government regulation and questions about the impact of legislation.

Debate about law-making authority may stall legislative initiatives. After the Parliamentary Standing Committee on Health produced its report on childhood obesity, Bloc Québé-

\section{Key points}

- Modern environments promote overeating and sedentary behaviour and have created an epidemic of chronic disease.

- Legal measures are one policy tool that can be used to promote healthier eating and more physical activity.

- In Canada, jurisdictional wrangling, the threat of legal challenges, ideological opposition and questions about effectiveness may stall adoption of novel legislation.

- Ongoing evaluation of legislative measures can provide evidence-based guidance on how to proceed.

cois members criticized the committee for "extending the study to areas that are outside the federal government's jurisdiction." 2 When a private member's bill in Ontario proposed to regulate trans fatty acid content and disclosure of nutritional information on restaurant menus, the provincial premier responded by stating that the federal government should take the lead. ${ }^{13}$

\section{Potential roadblocks}

Lack of authority is not a significant bar to action, however, because both federal and provincial governments have constitutional powers to enact health-related laws. ${ }^{14}$ This shared jurisdiction allows government to act in complementary ways, but it could be a source of delay while one level of government waits for another to act. The legislative initiatives described in Table 2 could serve as models for more consistent adoption across the country. Taxation and spending powers can be used by both levels of government: they could offer tax credits for physical activity but tax food and beverages that are high in calories and low in nutritional value. Advertising can be restricted through federal authority over broadcast media and provincial authority over business regulation and consumer protection. With constitutional authority over education, the provinces can use school legislation to impose mandatory requirements for nutrition and

From the Health Law Institute (Ries, Tigerstrom), University of Alberta, Edmonton, Alta., the Faculty of Law (Ries), University of Victoria, Victoria, $\mathrm{BC}$, and the College of Law and School of Public Health (Tigerstrom), University of Saskatchewan, Saskatoon, Sask.

CMAJ 2010. DOI:10.1503/cmaj.091403 
physical activity. Provincial public health statutes also confer power to protect and promote health; notably, British Columbia's new Public Health Act includes the power to regulate factors implicated in chronic disease. ${ }^{15}$ Under its criminal law jurisdiction, the federal government can prohibit or regulate health hazards and impose labelling requirements or advertising restrictions that discourage the consumption of hazardous products.

Governments may be concerned about legal challenges from the food industry. The most likely claim against adver- tising restrictions or labelling legislation would be infringement of freedom of expression, but such laws are defensible if they target a serious health or social problem in a reasonable way. The Supreme Court of Canada upheld Quebec's ban on advertising directed at children under age $13^{16}$ and federal tobacco legislation, including advertising restrictions and labelling requirements, ${ }^{17}$ as justifiable restrictions on commercial speech.

In addition to these legal concerns, ideological opposition to the so-called "nanny state" (whereby governments assume

Table 1: Summary of recommendations from reports for legislation on obesity (part 1 of 2)

\begin{tabular}{|c|c|c|c|c|c|}
\hline Report & Food labelling & Food advertising & Food content & $\begin{array}{l}\text { Pricing and } \\
\text { economic } \\
\text { incentives }\end{array}$ & $\begin{array}{l}\text { Food and physical } \\
\text { activity in school } \\
\text { and child care }\end{array}$ \\
\hline $\begin{array}{l}\text { British Columbia, } \\
\text { Select Standing } \\
\text { Committee on } \\
\text { Health }^{3}\end{array}$ & $\begin{array}{l}\text { Develop (in } \\
\text { cooperation with } \\
\text { industry) "warning } \\
\text { labels" for foods } \\
\text { high in fat, sugar } \\
\text { and sodium }\end{array}$ & $\begin{array}{l}\text { "Enhance" self- } \\
\text { regulation of } \\
\text { advertising to } \\
\text { children under } 12 \\
\text { years of age }\end{array}$ & $\begin{array}{l}\text { Negotiate } \\
\text { voluntary } \\
\text { reductions in fat, } \\
\text { sugar and sodium } \\
\text { content }\end{array}$ & $\begin{array}{l}\text { Remove sales tax } \\
\text { exemption for } \\
\text { candies and } \\
\text { confectionary, soft } \\
\text { drinks, and foods } \\
\text { not recommended } \\
\text { under food } \\
\text { guidelines for } \\
\text { schools; investigate } \\
\text { new "junk food } \\
\text { taxes" }\end{array}$ & $\begin{array}{l}\text { Order removal } \\
\text { from vending } \\
\text { machines and food } \\
\text { outlets of products } \\
\text { not recommended } \\
\text { in food guidelines } \\
\text { for schools; } \\
\text { prohibit sales of } \\
\text { these foods by } \\
\text { outlets in } \\
\text { government } \\
\text { properties }\end{array}$ \\
\hline $\begin{array}{l}\text { Ontario, Chief } \\
\text { Medical Officer of } \\
\text { Health }^{4}\end{array}$ & $\begin{array}{l}\text { Extend } \\
\text { requirement for } \\
\text { nutrition labels to } \\
\text { fresh meat, poultry } \\
\text { and fish; require } \\
\text { large chain } \\
\text { restaurants to } \\
\text { disclose basic } \\
\text { nutrition facts }\end{array}$ & $\begin{array}{l}\text { Explore options to } \\
\text { control food } \\
\text { advertising that } \\
\text { targets children }\end{array}$ & $\begin{array}{l}\text { Phase out trans } \\
\text { fatty acids from } \\
\text { processed foods }\end{array}$ & $\begin{array}{l}\text { Investigate impact } \\
\text { of decreasing food } \\
\text { prices, especially } \\
\text { for communities } \\
\text { where healthy } \\
\text { foods are } \\
\text { expensive }\end{array}$ & $\begin{array}{l}\text { Ensure healthy } \\
\text { food and physical } \\
\text { activity in daycare } \\
\text { settings, and that } \\
\text { schools and school } \\
\text { boards have } \\
\text { guidelines on food }\end{array}$ \\
\hline
\end{tabular}


a paternalistic role) may dissuade governments from adopting potentially controversial laws. The Lalonde report, so influential in advancing a "social determinants of health model" three decades ago, squarely stated the point: "The ultimate philosophical issue ... is whether, and to what extent, government can get into the business of modifying human behaviour, even if it does so to improve health." ${ }^{18}$ This debate persists today. A member of Ontario's legislature expressed classic opposition to public health intervention in his criticism of the proposed law to disclose trans fatty acid content and nutritional value on menus: "I believe in legislation, generally speaking, that protects me from you and you from me. I don't like legislation that purports to protect me from myself, and that's what this kind of legislation is."19

Those who accept a government role for regulation may nonetheless question the efficacy of legal measures in influencing healthier behaviour. A member of Alberta's Legislative Assembly criticized a proposed tax credit for physical activity in that province: “... we're kidding ourselves if we think a small monetary reward will incent Albertans to

Table 1: Summary of recommendations from reports for legislation on obesity (part 2 of 2)

\begin{tabular}{|c|c|c|c|c|c|}
\hline Report & Food labelling & Food advertising & Food content & $\begin{array}{l}\text { Pricing and } \\
\text { economic } \\
\text { incentives }\end{array}$ & $\begin{array}{l}\text { Food and physical } \\
\text { activity in school } \\
\text { and child care }\end{array}$ \\
\hline $\begin{array}{l}\text { Australia, } \\
\text { Preventative } \\
\text { Health Taskforce }^{8}\end{array}$ & $\begin{array}{l}\text { Include retailers } \\
\text { and restaurants in } \\
\text { national system of } \\
\text { food labelling }\end{array}$ & $\begin{array}{l}\text { Limit television } \\
\text { advertising of } \\
\text { foods high in } \\
\text { calories, low in } \\
\text { nutrition to } \\
\text { children }\end{array}$ & $\begin{array}{l}\text { Regulate trans } \\
\text { fatty acid, } \\
\text { saturated fat, } \\
\text { sodium and sugar } \\
\text { content }\end{array}$ & $\begin{array}{l}\text { Consider food } \\
\text { pricing strategies } \\
\text { (e.g., taxing } \\
\text { unhealthy foods); } \\
\text { promote active } \\
\text { forms of } \\
\text { commuting and } \\
\text { recreation through } \\
\text { subsidies and } \\
\text { taxation }\end{array}$ & $\begin{array}{l}\text { Support school } \\
\text { initiatives on } \\
\text { healthy eating and } \\
\text { physical activity; } \\
\text { ensure that school } \\
\text { policies and } \\
\text { environments help } \\
\text { students to } \\
\text { maintain healthy } \\
\text { weights, healthy } \\
\text { diets and physical } \\
\text { activity }\end{array}$ \\
\hline $\begin{array}{l}\text { New Zealand, } \\
\text { Health Committee }^{9}\end{array}$ & $\begin{array}{l}\text { Develop (and } \\
\text { regulate if } \\
\text { necessary) "traffic } \\
\text { light" or similar } \\
\text { labelling }\end{array}$ & $\begin{array}{l}\text { Extend current } \\
\text { restriction on } \\
\text { advertising during } \\
\text { children's } \\
\text { television } \\
\text { programs; restrict } \\
\text { or set targets for } \\
\text { regulating } \\
\text { marketing of } \\
\text { unhealthy food } \\
\text { and drink to } \\
\text { children }\end{array}$ & $\begin{array}{l}\text { Set targets for } \\
\text { reformulation of } \\
\text { foods high in } \\
\text { calories }\end{array}$ & & $\begin{array}{l}\text { Remove unhealthy } \\
\text { food and beverage } \\
\text { products from } \\
\text { schools (majority); } \\
\text { include promotion } \\
\text { of healthy eating } \\
\text { and physical } \\
\text { activity in } \\
\text { performance } \\
\text { evaluations for } \\
\text { schools and early } \\
\text { childhood centres }\end{array}$ \\
\hline $\begin{array}{l}\text { World Health } \\
\text { Organization }\end{array}$ & $\begin{array}{l}\text { Consider requiring } \\
\text { nutritional } \\
\text { information; } \\
\text { disallow } \\
\text { misleading health } \\
\text { claims }\end{array}$ & $\begin{array}{l}\text { Work with } \\
\text { consumer groups } \\
\text { and private sector } \\
\text { to develop } \\
\text { approaches to deal } \\
\text { with marketing to } \\
\text { children, } \\
\text { sponsorship, } \\
\text { promotion and } \\
\text { advertising }\end{array}$ & $\begin{array}{l}\text { Consider measures } \\
\text { to encourage } \\
\text { reductions in } \\
\text { sodium, } \\
\text { hydrogenated oil } \\
\text { and sugar content }\end{array}$ & $\begin{array}{l}\text { Consider using } \\
\text { taxation, subsidies } \\
\text { or direct pricing to } \\
\text { encourage healthy } \\
\text { eating and physical } \\
\text { activity; take } \\
\text { healthy nutrition } \\
\text { into account in } \\
\text { agricultural policy }\end{array}$ & $\begin{array}{l}\text { Adopt policies to } \\
\text { support healthy } \\
\text { diets at school and } \\
\text { limit availability of } \\
\text { products high in } \\
\text { sodium, sugar and } \\
\text { fat }\end{array}$ \\
\hline
\end{tabular}


Table 2: Summary of Canadian legislative initiatives for healthy eating and physical activity (part 1 of 2)

\begin{tabular}{|c|c|}
\hline Jurisdiction & Legislative initiatives \\
\hline \multicolumn{2}{|l|}{ Federal } \\
\hline Information disclosure & $\begin{array}{l}\text { Food and Drugs Act and Regulations require a nutrition facts table on most } \\
\text { prepackaged foods that provides information about calorie content and certain } \\
\text { nutrients, including fats, sugars and sodium }\end{array}$ \\
\hline Advertising & $\begin{array}{l}\text { Bill C-324, An Act to Amend the Competition Act and the Food and Drugs Act, a } \\
\text { private member's bill, would prohibit commercial food advertising aimed at children } \\
\text { younger than } 13\end{array}$ \\
\hline Food content & $\begin{array}{l}\text { Bill C-251, An Act to Amend the Food and Drugs Act, a private member's bill, would } \\
\text { restrict trans fatty acid content in oils and fats intended for human consumption }\end{array}$ \\
\hline Physical activity & $\begin{array}{l}\text { Children's Fitness Tax Credit provides a tax credit (up to } \$ 500 \text { ) for eligible fitness } \\
\text { expenses paid by parents to register a child in a prescribed program of physical } \\
\text { activity }\end{array}$ \\
\hline \multicolumn{2}{|l|}{ Alberta } \\
\hline Physical activity & $\begin{array}{l}\text { Bill 206, Alberta Personal Income Tax (Physical Activity Credit) Amendment Act, passed } \\
\text { a fitness tax credit (up to } \$ 500 \text { ) in November 2008, but it has not been implemented } \\
\text { (not funded in the April } 2009 \text { budget) }\end{array}$ \\
\hline \multicolumn{2}{|l|}{ British Columbia } \\
\hline $\begin{array}{l}\text { Food service } \\
\text { establishments }\end{array}$ & $\begin{array}{l}\text { Proposed restrictions of trans fatty acid content in prepared foods in food service } \\
\text { establishments, including restaurants and schools, are to be implemented by } \\
\text { regulation under the new Public Health Act, which authorizes regulation of } \\
\text { conditions, things or activities that constitute a "health impediment" }\end{array}$ \\
\hline Public health plans & $\begin{array}{l}\text { New Public Health Act, effective Mar. } 31,2009 \text {, authorizes the Minister of Health to } \\
\text { order public bodies to establish plans to "identify, prevent and mitigate the adverse } \\
\text { effects of health impediments," which include factors that cause chronic disease or } \\
\text { whose cumulative effects adversely affect health }\end{array}$ \\
\hline \multicolumn{2}{|l|}{ Manitoba } \\
\hline \multirow[t]{2}{*}{ Food in schools } & $\begin{array}{l}\text { Bill 2, Public Schools Amendment Act (Trans Fat and Nutrition), although not yet in } \\
\text { force, requires that each school establish a written policy about food and nutrition } \\
\text { and report on progress in implementing the policy in the annual school plan; it also } \\
\text { restricts artificial trans fatty acid content in foods provided by or sold in schools }\end{array}$ \\
\hline & $\begin{array}{l}\text { Healthy Child Manitoba Act guides "the development, implementation and evaluation } \\
\text { of the Healthy Child Manitoba strategy," a prevention and early intervention strategy } \\
\text { to promote healthy eating and physical activity; it also addresses such topics as } \\
\text { parenting skills, daycare programs, fetal alcohol spectrum disorder and healthy school } \\
\text { environments }\end{array}$ \\
\hline
\end{tabular}

change their lives in such a drastic way. A comprehensive approach is needed if a tax incentive is going to ultimately produce results." ${ }^{20}$

It is true that, as lessons in tobacco control show, a "portfolio of policies" is needed to combat chronic diseases stemming from unhealthy modern environments. ${ }^{21}$ However, a comprehensive approach must be built piece by piece, and it would be a mistake to allow skepticism about the impact of single legislative or policy interventions to preclude any action at all. Massive shifts have occurred in the conditions in which people live, work and play, and it will be difficult to isolate and assess the role of the law in countering the unhealthy impact of these shifts. Yet, evidence about environments and behaviour can help identify defensible legislative interventions. For example, the amount of food consumed outside the home suggests that requiring information disclosure in food service establishments is a potential policy option. Evidence from areas such as behavioural eco- nomics can provide some insight on how consumers might react to higher prices for snack foods with low nutritional value or tax credits for physical activity. It is important to assess the results of specific legislative measures; researchers are already making concerted efforts to study the impact of laws on public health. ${ }^{22}$ Early evaluations of novel approaches in the US and elsewhere can help identify strengths and weaknesses, and promising interventions can be adapted to Canada's social and cultural context.

With ongoing assessment, legislation can be adjusted over time to ensure that the objectives of public health are promoted. The personal and social harm associated with the increasing burden of chronic disease is a matter of urgent public concern. In an area so complex and controversial, not everyone will agree on the best way forward; however, the use of legal measures to promote healthier nutrition and physical activity, especially among children, deserves more attention and action from Canadian legislators. 
Table 2: Summary of Canadian legislative initiatives for healthy eating and physical activity (part 2 of 2)

\begin{tabular}{|c|c|}
\hline Jurisdiction & Legislative initiatives \\
\hline \multicolumn{2}{|l|}{ New Brunswick } \\
\hline $\begin{array}{l}\text { Physical activity in } \\
\text { schools }\end{array}$ & $\begin{array}{l}\text { Healthy Students Act, proposed in } 2005 \text { (Bill 33) and } 2006 \text { (Bill 44), would have } \\
\text { required a healthy students advisory committee to promote physical activity in schools } \\
\text { and ensure that students receive } 150 \text { minutes per week of physical education }\end{array}$ \\
\hline \multicolumn{2}{|l|}{ Nova Scotia } \\
\hline Physical activity & $\begin{array}{l}\text { Financial Measures Act, effective Jan. } 1,2009 \text {, provides a healthy living tax credit of up } \\
\text { to } \$ 500 \text { for sports or recreational activities; previous private member's bill (Bill 106, } \\
\text { Income Tax Act Amendment) proposed a tax credit for recreational and physical } \\
\text { activities, specifically for people aged } 65 \text { and older }\end{array}$ \\
\hline $\begin{array}{l}\text { Physical activity in } \\
\text { schools }\end{array}$ & $\begin{array}{l}\text { Bill 115, An Act to Amend the Education Act, a private member's bill, would require at } \\
\text { least } 30 \text { minutes of physical activity each school day; previous private member's bill in } \\
2006 \text { (Bill 90, Student Fitness Act) sought to create a provincial healthy students } \\
\text { advisory committee that would require } 150 \text { minutes of physical education per week }\end{array}$ \\
\hline \multicolumn{2}{|l|}{ Ontario } \\
\hline Advertising & $\begin{array}{l}\text { Bill } 53 \text { (2008), An Act to Amend the Consumer Protection Act, } 2002 \text { would prohibit } \\
\text { "commercial advertising for food or drink that is directed at persons under } 13 \text { years of age" }\end{array}$ \\
\hline Food in schools & $\begin{array}{l}\text { Bill 8, Healthy Food for Healthy Schools Act, } 2008 \text { amends Education Act to establish } \\
\text { policies and guidelines for school nutrition standards and for food and beverages } \\
\text { available in schools; it also regulates trans fatty acid content of food in schools }\end{array}$ \\
\hline $\begin{array}{l}\text { Food service } \\
\text { establishments }\end{array}$ & $\begin{array}{l}\text { Bill 156, Healthy Decisions for Healthy Eating Act, } 2009 \text { would require food service } \\
\text { establishments (fast food) with total gross annual revenues of more than } \$ 5 \text { million to } \\
\text { disclose certain nutritional information for foods and beverages; it would also limit } \\
\text { trans fatty acid content }\end{array}$ \\
\hline Public health standards & $\begin{array}{l}\text { Provincial Public Health Standards, issued under the Health Protection and Promotion } \\
\text { Act, are "guidelines for the provision of mandatory health programs and services;" the } \\
\text { standards impose obligations on boards of health to monitor and promote healthy } \\
\text { eating, physical activity and other health-related behaviours; the boards work with } \\
\text { schools, workplaces, municipalities and community partners in comprehensive health } \\
\text { promotion programs and services }\end{array}$ \\
\hline \multicolumn{2}{|l|}{ Quebec } \\
\hline Advertising & $\begin{array}{l}\text { Since } 1980 \text {, Consumer Protection Act has prohibited commercial advertising directed } \\
\text { at children younger than age } 13\end{array}$ \\
\hline Financial measures & $\begin{array}{l}\text { An Act to Establish the Fund for the Promotion of a Healthy Lifestyle, enacted in 2007, } \\
\text { establishes a fund for programs that promote healthy eating and physical activity; part } \\
\text { of the funding ( } \$ 20 \text { million/yr) is through revenue collected under the Tobacco Tax Act }\end{array}$ \\
\hline
\end{tabular}

This article has been peer reviewed.

Competing interests: None declared.

Contributors: Both authors contributed to the conception of and research for the article. Nola Ries prepared the first draft of this article. Barbara von Tigerstrom conducted the research and analysis for information summarized in Table 1 , and Nola Ries did so for Table 2. Both authors contributed equally to the revision of the article and approved the final version submitted for publication.

Funding: The authors acknowledge funding from the Canadian Institutes of Health Research, grant MOP81162. Nola Ries also receives funding from the Alberta Cancer Prevention Legacy Fund, Alberta Health Services.

\section{REFERENCES}

1. Policy and action for cancer prevention - food, nutrition, and physical activity: a global perspective. Washington (DC): World Cancer Research Fund/American Institute for Cancer Research; 2009. p. 86. Available: www.dietandcancerreport .org (accessed 2010 Jan. 5).

2. Standing Committee on Health. Healthy weights for healthy kids. Ottawa (ON): House of Commons; 2007. p. 57. Available: www.ccfn.ca/pdfs/HealthyWeights ForHealthyKids.pdf (accessed 2010 Jan. 5).
3. Select Standing Committee on Health. A strategy for combatting childhood obesity and physical inactivity in British Columbia. Victoria (BC): Legislative Assembly of British Columbia; 2006. Available: www.leg.bc.ca/CMT/38thparl/session-2 /health/reports/Rpt-Health-38-2-29Nov2006/Rpt-Health-38-2-29Nov2006-COOBC .htm (accessed 2010 Jan. 12).

4. Chief Medical Officer of Health. 2004 Chief Medical Officer of Health report: healthy weights, healthy lives. Toronto $(\mathrm{ON})$ : Ministry of Health and Long-term Care; 2004. Available: www.health.gov.on.ca/english/public/pub/ministry _reports/cmoh04_report/healthy_weights_112404.pdf (accessed 2010 Jan. 12).

5. Select Committee on Wellness. Wellness ... we each have a role to play: final report of the Select Committee on Wellness. Fredericton (NB): The Committee; 2008. Available: www.gnb.ca/legis/Promos/Wellness/pdf/FinalReport-Wellness-e .pdf (accessed 2010 Jan. 12).

6. Institute of Medicine Committee on Prevention of Obesity in Children and Youth. Koplan JP, Liverman CT, Kraak VA, editors. In: Preventing childhood obesity: health in the balance. Washington (DC): National Academies Press; 2005.

7. Cross-Government Obesity Unit. Healthy weight, healthy lives: a cross-government strategy for England. Department of Health and Department of Children, Schools and Families; 2008. Available: www.dh.gov.uk/prod_consum_dh/groups/dh_digital assets/documents/digitalasset/dh_084024.pdf (accessed 2010 Jan. 12).

8. Preventative Health Taskforce. Obesity in Australia: a need for urgent action. Commonwealth of Australia; 2008. Available: www.preventativehealth.org.au /internet/preventativehealth/publishing.nsf/Content/E233F8695823F16CCA2574D D00818E64/\$File/obesity-jul09.pdf (accessed 2010 Jan. 12).

9. Health Committee. Inquiry into obesity and type 2 diabetes in New Zealand. New Zealand: House of Representatives; 2007. Available: www.parliament.nz/NR 
/rdonlyres/47F52D0D-0132-42EF-A297-6AB08980C0EA/62831/DBSCH_SCR _3868_5337.pdf (accessed 2010 Jan. 12).

10. Commission of the European Communities. Promoting healthy diets and physical activity: a European dimension for the prevention of overweight, obesity and chronic diseases. Brussels (Belgium): The Commission; 2005.

11. World Health Organization. European Ministerial Conference on Counteracting Obesity: conference report. Copenhagen (Denmark): World Health Organization Regional Office for Europe; 2007. Available: www.euro.who.int/document /E90143.pdf (accessed 2010 Jan. 12).

12. Supplement to " $F$ as in fat: how obesity policies are failing America, 2009" obesityrelated legislation action in States, update. Washington (DC): Trust for America's Health. Available: http://healthyamericans.org/reports/obesity2009/StateSupplement 2009.pdf (accessed 2010 Jan. 5)

13. Canadian Press. Ottawa should lead on childhood obesity: McGuinty. Toronto (ON): CTV News; April 8, 2009. Available: www.ctv.ca/servlet/ArticleNews /story/CTVNews/20090408/mcguinty_obesity_090408/20090408?hub=Health\&s _name $=($ accessed 2010 Jan. 5).

14. Ries NM. Legal foundations of public health law. In: Bailey TM, Caulfield T, Ries NM, editors. Public health law \& policy in Canada, 2nd ed. Markham (ON): LexisNexis Canada; 2008. p. 7-36.

15. Public Health Act, S.B.C., 2008, c. 28
16. Irwin Toy Ltd. v. Quebec (Attorney General), [1989] 1 S.C.R. 927.

17. Canada (Attorney General) v. JTI-Macdonald Corp., [2007] S.C.C. 30.

18. Lalonde M. A new perspective on the health of Canadians. Ottawa (ON): Government of Canada; 1981.

19. Canada HC Debates. 39-1. Available: http://hansardindex.ontla.on.ca/hansardeissue 139-1/1135.htm (accessed 2010 Jan. 5).

20. Debates of the Legislative Assembly of Alberta. 27th Legislature, First Session; November 17, 2008. Available: www.assembly.ab.ca/ISYS/LADDAR_files/docs /hansards/han/legislature_27/session_1/20081117_1330_01_han.pdf (accessed 2010 Jan. 5).

21. Foresight - tackling obesities: future choices, project report. London (UK): Government Office for Science; 2007. Available: www.foresight.gov.uk/OurWork /ActiveProjects/Obesity/Obesity.asp (accessed 2010 Jan. 5).

22. Moulton AD, Mercer SL, Popovic T, et al. The scientific basis of law as a public health tool. Am J Public Health 2009;99:17-24.

Correspondence to: Nola M. Ries, Faculty of Law, University of Victoria, PO Box 2400, STN CSC, Victoria BC V8W 3H7; nmries@uvic.ca/nries@law.ualberta.ca

\section{Change of address}

We require 6 to 8 weeks' notice to ensure uninterrupted service. Please send your current mailing label, new address and the effective date of change to:

\section{CMA Member Service Centre}

1870 Alta Vista Dr. Ottawa ON K1G 6R7

tel $888855-2555$ or $613731-8610 \times 2307$ fax $613236-8864$ cmamsc@cma.ca

\section{Changement d'adresse}

II nous faut de 6 à 8 semaines d'avis afin de vous assurer une livraison ininterrompue. Veuillez faire parvenir votre étiquette d'adresse actuelle, votre nouvelle adresse et la date de la prise d'effet du changement, à l'attention du

\section{Centre des services aux membres de l'AMC}

1870, prom. Alta Vista

Ottawa ON K1G 6R7

tél 888 855-2555 ou

$613731-8610 \times 2307$

fax 613 236-8864

cmamsc@cma.ca

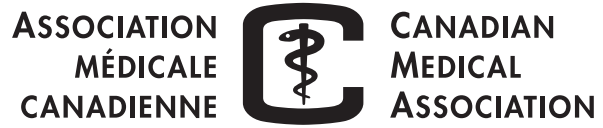

